\title{
Gilead injects own generics into shrinking HCV drug market
}

In an unusual move, Gilead Sciences said in September that it will sell generic versions of its own hepatitis $\mathrm{C}$ virus (HCV) drugs in the US through a subsidiary, Asegua Therapeutics. These 'authorized generics' will be on the market in January 2019, even though the patents on Gilead's blockbuster HCV drugs Harvoni (ledipasvir/sofosbuvir) and Epclusa (sofosbuvir/velpatasvir) don't begin to expire until 2028. And with generic versions priced at $\$ 24,000$ for the most common courses of therapy, they will be substantially cheaper than Harvoni $(\$ 63,000)$ and Epclusa $(\$ 74,760)$. Those lower list prices, however, "more closely reflect the discounts that health insurers and government payers receive today," according to Gilead. In short, Gilead's generics aren't actually necessarily cheaper than its existing brands, but the company is pulling aside the curtain that obscures the drugs' discounts and rebates in a way that will allow some patients to potentially share in the savings enjoyed by insurance plans and the pharmacy benefit managers who negotiate on their behalf. Gilead estimates the new generics could save patients up to $\$ 2,500$ per course of therapy.
What about simply lowering Harvoni and Epclusa's list prices? Gilead's existing contracts with health insurers and laws that govern prices paid by the US Medicare and Medicaid programs prevent it from making drastic cuts. The newly minted generics, however, will not have new brand names and will be eligible to be substituted for Gilead's brands at the pharmacy, subject to various state laws and payer contracts. The pharmacy benefit manager Express Scripts called Gilead's move "a step in the right direction" and a "win for payers and patients." Eventually, Gilead's higher priced brands should be eclipsed entirely by the generics.

Gilead's generics are "a statement about the warped incentives in the drug channel system" in the US, says Adam Fein, president of Pembroke Consulting in Philadelphia-a system whereby payers may choose a higher priced product over a cheaper alternative because of the rebates they'll receive. Fein says that while other companies could attempt to emulate Gilead's authorized generics strategy, the HCV market has some unique dynamics that might limit the usefulness of such a move. For one, $\mathrm{HCV}$ is a very competitive market, in part because "the more successful you are at market-

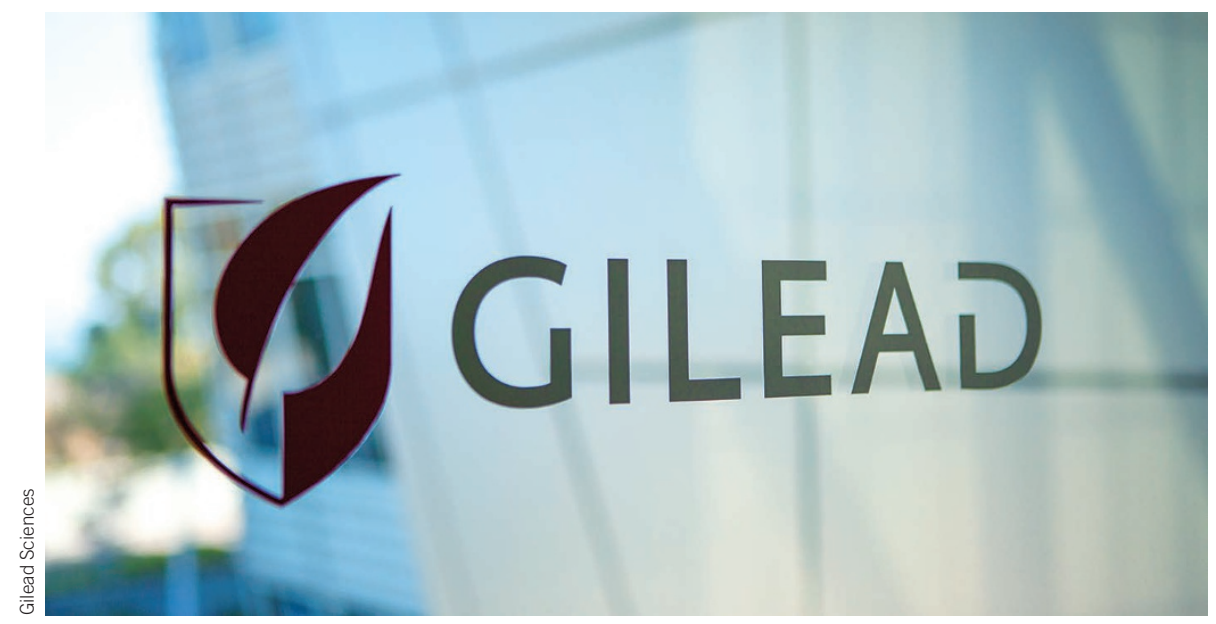

Gilead has taken an unexpected route to ensure it continues to benefit from its HCV drug franchise. ing your product, the fewer patients you have to serve: it's a cure," he says. Because it's a shrinking pool of patients, companies have been competing aggressively by lowering prices, so there's a large list-to-net price spread for Gilead's different products, whereas competitor Abbvie has set a low list price for Mavyret (glecaprevir/ pibrentasvir) from the outset.

Meanwhile, thanks to ramped-up political and public pressure in the US, pharmaceutical companies are becoming "somewhat self-regulating" in terms of taking fewer and smaller price increases on their products, which has curtailed their normal ways of increasing revenue, says Jeff Berkowitz, CEO of the market access specialists Real Endpoints of Madison, New Jersey, and a former health insurance and pharmacy executive. "So we'll see more and more clever machinations to create additional value. People will be watching Gilead carefully to see how this works," he says.

Harvoni was approved in October 2014. In its first full year on the market Harvoni racked up $\$ 13.9$ billion in worldwide revenue. Since then Gilead's HCV revenue has been steadily and forcefully eroded by the competition Fein describes: in 2018, analysts expect Gilead to take in just over $\$ 2$ billion in HCV revenue. With the new generics, Gilead could win market share from Mavyret, which has a list price of $\$ 26,400$. But Evercore ISI analyst Umer Raffat says it's likely that Abbvie will respond by further lowering the prices of its own HCV therapies.

Although Gilead's first-generation drug HCV Sovaldi (sofosbuvir) proved a revolutionary cure for a serious disease when it launched in 2013, the drug's $\$ 1,000$-a-pill price tag fuelled public antipathy toward drug prices in the US. That sentiment could now reverse as the company introduces generic versions of Harvoni and Epclusa only five years after reaching market. The 'authorized generics' may well restore some goodwill even as they help Gilead keep the blockbuster franchise alive a little while longer.

Christopher Morrison Yardley, Pennsylvania

\section{PODCAST}

\section{First rounders: Christoph Lengauer}

Christoph Lengauer is a venture partner at Third Rock Ventures, the president of Celsius Therapeutics, and executive vice president at Blueprint Medicines. His conversation with Nature Biotechnology covers growing up in Austria, why he nearly gave up research for a career helping settle refuguees, and his role in the Henrietta Lacks story.

https://www.acast.com/naturebiotechnologypodcast

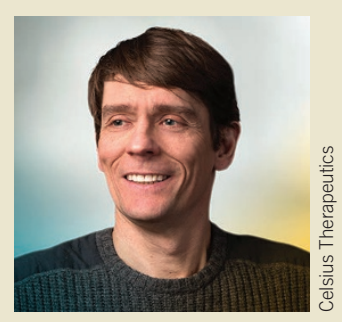

